\author{
Asian Journal of \\ Medical and Biological Research \\ ISSN 2411-4472 (Print) 2412-5571 (Online) \\ www.ebupress.com/journal/ajmbr
}

\title{
Article \\ X-Ray flourescence (XRF) elemental composition of Euphorbia hirta Linn (Asthma weed) as a medicinal plant
}

\author{
Fatimah M Kntapo, Abubakar G. Salisu and Rukaiyat M Said \\ Department of Applied Science, Kaduna Polytechnic, Nigeria \\ ${ }^{*}$ Corresponding author: Fatimah M Kntapo, Department of Applied Science, Kaduna Polytechnic, Nigeria. \\ Phone: 07068360166; E-mail: fkntapo@gmail.com
}

Received: 01 March 2018/Accepted: 22 March 2018/ Published: 29 March 2018

\begin{abstract}
Euphobia hirta (Eh) was subjected to elemental analysis using X-ray fluorescence (XRF), and the results revealed the following concentrations of the elements : sulphur $(4.128 \mathrm{mg} / \mathrm{kg})$, potassium $(58.755 \mathrm{mg} /$ $\mathrm{kg})$, calcium $(34.102 \mathrm{mg} / \mathrm{kg})$, scandium $(0.256 \mathrm{mg} / \mathrm{kg})$, titanium $(0.348 \mathrm{mg} / \mathrm{kg})$, iron $(2.124 \mathrm{mg} / \mathrm{mg})$, zinc $(0.108$ $\mathrm{mg} / \mathrm{kg})$, rubidium $(0.040 \mathrm{mg} / \mathrm{kg})$, strontium $(0.089 \mathrm{mg} / \mathrm{kg})$, zireonium $(0.026 \mathrm{mg} / \mathrm{kg})$, molybdenum $(0.006 \mathrm{mg} / \mathrm{kg})$ and thorium $(0.120 \mathrm{mg} / \mathrm{kg})$ respectively. All elements analysed above were within the permissible limit set by World Health Organization (WHO) and Food and Agricultural Organization (FAO).Vanadium, chromium, manganese, cobalt, nickel, copper, arsenic, selenium, palladium, silver, cadmium, tin, antimony, tellurium, caesium, barium, tungsten, gold, mercury and lead were not detected in the sample.
\end{abstract}

Keywords: Euphobiahirta (Eh); X-ray fluorescence (XRF); elements composition; medicine

\section{Introduction}

Euphorbia hirta Linn. (Eh) is one of the herbs belonging to the family Euphorbiaceae, commonly called Asthma weed and vanacular names include "Iroko- Iju" in Yoruba,'Ugwa" in Igbo and "Nononkurciya" in Hausa. They are frequently seen occupying open waste spaces and grasslands, road sides, and pathways in Nigeria. Though a native of central America, the herb is widely cultivated throughout the tropics, especially in west, central and east Africa. As seen in figure 1, it is usually erect, slender-stemmed, spreading up to $45 \mathrm{~cm}$ tall, though sometimes can be seen lying down. The plant is an annual broad-leaved herb that has a hairy stem with many branches from the base to the top (Adedapo et al., 2005).

The stem and leaves produce white or milky juice when cut. The medicinal usefulness of this herb has been the subject of numerous chemical and microbiological studies, such medicinal values include cough, catarrh, hay fever, vaginal candiditis, pulmonary ailement, dysentery, conjuctivities, aphrodisiac, increase lactation, adjust breast shape and hypertension (Adedapo et al., 2005). (Olayiwola, 2013) indicated the presence of high concentration of $\mathrm{Ca}(76.7 \pm 3.00 \mathrm{mg} / \mathrm{g})$ and trace concentration of $\mathrm{Fe}(0.53 \pm 0.05 \mathrm{mg} / \mathrm{g})$ in the leaves of $E$ hirta. (Guessan et al. 2015) indicated that the aerial parts of Eh contains $\mathrm{Cr}, \mathrm{Zn}, \mathrm{K}, \mathrm{Ca}$ and $\mathrm{Mg}$.

The curative effects of medicinal plants used in the traditional system of medicines include the presence of very minute quantities of trace elements. Important constituents of the body such as enzymes are intimately associated with chemical elements. Elements, particularly essential trace elements play both curative and preventive roles in fighting diseases such as iron in anemia and iodine in goiter. At present about 14 such elements are considered to influence the state of health and diseases of animals, plants and human beings, these elements are iron( $\mathrm{Fe})$, copper $(\mathrm{Cu})$, cobalt $(\mathrm{Co})$, nickel $(\mathrm{Ni})$, zinc $(\mathrm{Zn})$, manganese $(\mathrm{Mn})$, magnesium $(\mathrm{Mg})$, molybdenum (Mo), chronium (Cr), vanadium (V), lithium (Li), selenium (Se), flourine (F) and iodine (I). The deficiency of trace elements in human subjects can occur under mostpractical dietary conditions (Dghaim et al, 2015). 
Many diseases which have been considered incurable may now possibly be treated by balancing the equilibrium of these elements in the human body (Dghaim et al., 2015). Trace elements like $\mathrm{Fe}, \mathrm{Cu}, \mathrm{Zn}, \mathrm{Cu}, \mathrm{Mn}$, and Ni are essential nutrients but they become harmful and toxic when their concentration exceeds the recommended standards. Lead $(\mathrm{Pb})$ and cadmium $(\mathrm{Cd})$ are nonessential element they are extremely toxic even in very minute amounts. There are many elements present in the living organisms and scores of metabolic reactionsare attributed to them (Dghaim et al., 2015). It is well established that plants pick up elements from the soil, e.g., banana takes up potassium and turmeric accumulates large quantity of lead (Lynch and Braithwaite, 2005). It is generally believedthat herbal and natural products are safer than the synthetic or modern medicines but even some indigenous herbal products containelements as essential ingredients. Prolonged exposure to elements such as $\mathrm{Cd}, \mathrm{Cu}, \mathrm{Pb}, \mathrm{Ni}$, and $\mathrm{Zn}$ can cause deleterious health effects in humans.

All though many of traditional remedies are used safely, there have recently been an increasing number of case reports being published of elements poisoning after consumption. Dghaim et al. (2015) indicated that most of the 68 analysed medicinal plants contained unsafe levels of elements that exceeded the World Health Organization (WHO) permissible limits (PL), Cd (0.1-1.11 mg/kg), Pb (1.0-23.52 mg/kg), Cu (1.44$156.24 \mathrm{mg} / \mathrm{kg}), \mathrm{Zn} \quad(12.65-146.67 \mathrm{mg} / \mathrm{kg})$ and $\mathrm{Fe}(81.25-1101.22 \mathrm{mg} / \mathrm{kg})$. Indian Ayurvedic remedies were showed to have high levels of $\mathrm{Pb}, \mathrm{Hg}$ and As in Ayurvedic products sold in US (Lynch and Braithwaite, 2005). $\mathrm{X}$-ray fluorescence (XRF) spectrometry is an elemental analysis technique with broad application in science and industry. Modern XRF instruments are capable of analyzing solid, liquid, and thin-film samples for both major and trace (ppm-level) components (Buhrke et al., 1998). Queralt et al. (2005) reported Macro- and microelement contents of five medicinal plants (Taraxacum officinale Weber, Eucalyptus globulus Labill, Plantago lanceolata L., Matricaria chamomilla L. and Mentha piperita L.) and their infusions were evaluated by the combined use of $\mathrm{x}$-ray fluorescence (WDXRF and EDXRF, bulk raw plants) and inductively coupled plasma (ICP-MS and ICP-AES, infusions) techniques. The analytical methods allow the determination of 17 elements ( $\mathrm{Na}, \mathrm{Mg}, \mathrm{Al}, \mathrm{Si}, \mathrm{P}, \mathrm{S}, \mathrm{K}, \mathrm{Ca}, \mathrm{Ti}, \mathrm{Mn}, \mathrm{Fe}, \mathrm{Cu}, \mathrm{Zn}, \mathrm{As}, \mathrm{Rb}, \mathrm{Sr}$, and $\mathrm{Pb}$ ) both in plants and in the infusions. The use of XRF techniques offer a good multielemental approach for the rapid quality control of bulk raw plant materials whereas ICP techniques are well suited for the analytical control of infusions in order to ascertain the nutritional role of medicinal plants and thedaily dietary intake. Erick et al. (2015) reported for best detection of light elements $(\mathrm{Mg}-\mathrm{P})$, direct analysis on the surface of a pXRF provides data of highest sensitivity and accuracy (R2>0.90). The sensitivity and accuracy are not only dependent on the settings but also on the instrument's make and model. Elements such as S, K, and Ca can be reliably measured (R2 $>0.99,0.97$, and 0.93 , respectively) without the aid of a vacuum, although lower detection limits may be compromised. This research is to use X-ray fluorescence (XRF) spectrometry for elemental composition of Euphobiahirta (Eh) to ascertain it curative and preventive roles in fighting diseases if within the level of World health organization.

\section{Materials and Methods}

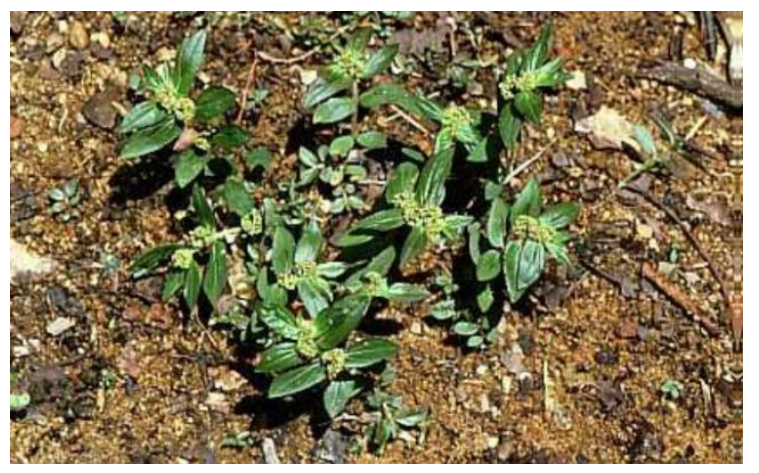

Figure 1. Photograph of Euphorbia hirta Linn.

\subsection{Sample Preparation}

The plant sample as shown in Figure 1 was obtained within Kaduna metropolis and was identified at the herbarium section in botany department of Biological Sciences A.B.U Zaria, and Voucher number 583 was given. The identified plant was air dried at ambient temperature, then crushed to powder using motor and pestle and stored separately in a sealed bottle. 


\subsection{XRF Spectroscopy}

Handheld thermo scientific NITON XL3t XRF analyzer with serial number \#81072 and model number X13t950 was used. The grounded powdered sample was placed on Thermo Scientific NITON XL3t XRF analyzer sample holder. The sample holder containing the sample was covered with a cellophane paper capped with sample holder cover. The covered sample holder was placed in XRF analyzer stand. The handheld XRF analyzer was powered on and the handheld XRF analyzer was placed on the cellophane covered sample holder for a period of 180 seconds. The handheld XRF analyzer was removed from the top of the sample and it was connected to PC where the NitonXRF software was powered on and the element detected by the analyzer along with their composition in \% ppm and spectra was exported on Microsoft Excel and PDF software respectively.

\section{Results and Discussion}

The following result as shown in Table 1 is the elemental compositions as analysed in the plant.

Table 1. Elemental Composition of $E h(\mathrm{mg} / \mathrm{kg})$.

\begin{tabular}{llllll}
\hline Element & Weight & Element & Weight & Element & Weight \\
\hline Sulphur & 4.128 & Copper & ND & Tin & ND \\
Potassium & 58.755 & Zinc & 0.108 & Antimony & ND \\
Calcium & 34.102 & Arsenic & ND & Tellurium & ND \\
Scandium & 0.256 & Selenium & ND & Caesium & ND \\
Titanium & 0.348 & Rubidium & 0.040 & Barium & ND \\
Vanadium & ND & Strontium & 0.089 & Tungsten & ND \\
Chronium & ND & Zirconium & 0.026 & Gold & ND \\
Manganese & ND & Molybdenum & 0.006 & Mercury & ND \\
Iron & 2.124 & Palladium & ND & Lead & ND \\
\hline
\end{tabular}

KEY:

$\mathrm{ND}=$ Not detected

Table 2: Established recommended daily intake and permissible limit of trace elements according to WHO/FAO.

\begin{tabular}{lll}
\hline Elements & Recommended daily intake & Permissible limit in plant \\
\hline $\mathrm{Mo}$ & $2 \mathrm{mg} / \mathrm{day}$ & $\mathrm{NE}$ \\
$\mathrm{Ca}$ & $750-800 \mathrm{mg} /$ day & $\mathrm{NE}$ \\
$\mathrm{Cr}$ & $25-35 \mu \mathrm{g} / / \mathrm{day}$ & $\mathrm{NE}$ \\
$\mathrm{Mn}$ & $1.8-2.3 \mathrm{mg} / \mathrm{day}$ & $200 \mathrm{mg} / \mathrm{kg}$ \\
$\mathrm{Fe}$ & $9.1-26.0 \mathrm{mg} / \mathrm{day}$ & $20 \mathrm{mg} / \mathrm{kg}$ \\
$\mathrm{Ni}$ & $1 \mathrm{mg} / \mathrm{day}$ & $1.5 \mathrm{mg} / \mathrm{kg}$ \\
$\mathrm{Cu}$ & $10 \mathrm{mg} / \mathrm{day}$ & $20-150 \mathrm{mg} / \mathrm{kg}$ \\
$\mathrm{Zn}$ & $4.2-14.0 \mathrm{mg} / \mathrm{day}$ & $50 \mathrm{mg} / \mathrm{kg}$ \\
$\mathrm{Rb}$ & $1.5 \mathrm{mg} / \mathrm{day}$ & $\mathrm{NE}$ \\
$\mathrm{Zr}$ & $125 \mathrm{mg} / \mathrm{day}$ & $\mathrm{NE}$ \\
$\mathrm{Cd}$ & $7.0 \mu \mathrm{g} / / \mathrm{day}$ & $0.3 \mathrm{mg} / \mathrm{kg}$ \\
$\mathrm{Pb}$ & $1.5 \mathrm{mg} /$ day & $10 \mathrm{mg} / \mathrm{kg}$ \\
\hline
\end{tabular}

Sources: (WHO/FAO, 2007); (Aweng et al., 2011); (Abdulmajeed et al., 2011)

Keys; Not established (NE), World Health Organization (WHO), Food and Agricultural Organisation (FAO).

Tables 1 list the elements determined in Euphobia hirta Eh by handheld thermo scientific NITON XL3t XRF analyzer with serial number \#81072 and model number X13t950 similar to work reported in literature (Queralt et al., 2005); (Erick et al., 2015). The presence of trace elements showed that the plantanalysed will be useful in influencing various body functions and activities positively. These elements are also beneficial in chemotherapy and are essential in human and animal health (Moses et al., 2002) such assulphur $(4.128 \mathrm{mg} / \mathrm{kg}$ ), potassium $(58.755 \mathrm{mg} / \mathrm{kg})$, calcium $(34.102 \mathrm{mg} / \mathrm{kg})$, scandium $(0.256 \mathrm{mg} / \mathrm{kg})$, titanium $(0.348 \mathrm{mg} / \mathrm{kg})$, iron $(2.124 \mathrm{mg} / \mathrm{mg})$, zinc $(0.108 \mathrm{mg} / \mathrm{kg})$, rubidium $(0.040 \mathrm{mg} / \mathrm{kg})$, strontium $(0.089 \mathrm{mg} / \mathrm{kg})$, zireonium $(0.026 \mathrm{mg} / \mathrm{kg})$, molybdenum $(0.006 \mathrm{mg} / \mathrm{kg})$ and thorium $(0.120 \mathrm{mg} / \mathrm{kg})$ respectively in decreasing concentration order of $\mathrm{K}>\mathrm{Ca}>\mathrm{S}>\mathrm{Fe}$ $>\mathrm{Ti}>\mathrm{Sc}>\mathrm{Th}>\mathrm{Zn}>\mathrm{Sr}>\mathrm{Rb}>\mathrm{Zr}>\mathrm{Mo}$ with highest value recorded as $58.755 \mathrm{mg} / \mathrm{Kg}$ and lowest value of 0.006 $\mathrm{mg} / \mathrm{Kg}$. This result is similar to work done on $E h$ by (Olayiwola, 2013) which indicated high concentration of 
$\mathrm{Ca}(76.7 \pm 3.00 \mathrm{mg} / \mathrm{g})$ but differ in having trace concentration of $\mathrm{Fe}(0.53 \pm 0.05 \mathrm{mg} / \mathrm{g})$. Guessan et al. (2015) indicated that the aerial parts of $E h$ contains $\mathrm{Cr}, \mathrm{Zn}, \mathrm{K}, \mathrm{Ca}$ and $\mathrm{Mg}$. The presence of high concentration of some elements seen in the samples may be due to the topography, soil-water-plant exchange complex andevapotranspiration of the environment (Adoum et al., 1998). Some classes of chemical compounds and elements found in the sample have been known to exert pharmacological effects while others are capable of protecting the active ingredients in the herb from decomposing either chemically or physiologically (Abdulrahman and Onyeyili, 2001). Herbs are significant nutritional sources of minerals. The major minerals (such as $\mathrm{Ca}, \mathrm{P}, \mathrm{Mg}, \mathrm{S}$, $\mathrm{K}$, and $\mathrm{Na}$ ) are structural components of tissues and function in cellular/ basal metabolism and acid-base balance and minor (trace) minerals (such as $\mathrm{Zn}, \mathrm{Si}, \mathrm{Mn}, \mathrm{Cu}, \mathrm{Fl}$, I and $\mathrm{Cr}$ ) are very important for hormones, vitamins and enzyme activity (Okwu, 2010).

Potassium $(\mathrm{K})$ is reported to be responsible for the repair of worn out cells, strong bones and teeth, building of red blood cells and for body mechanisms (WHO, 1996). Epidemiological studies and studies in animals subject to hypertension indicate that, diets high in potassium can reduce the risk of hypertension and possibly stroke (Yoshimura et al., 1991). It is good for pregnant women especially at the timeof delivery. Requirements of potassium in the body depend on factors such as age and health status and sex. Potassium is needed by the body for strong bones, healthy heart and muscles.

Calcium is an essential nutrient that plays a vital role in neuromuscular function, many enzyme-mediated processes, blood clotting, metabolic processes as well as providing rigidity to the skeleton. Calcium fluxes are also important mediators of hormonal effects on target organs through several intracellular signaling pathways (WHO, 2004). Where calcium intake is low, calcium supplement as part of the antenatal care is recommended for the prevention of preeclampsia (high blood pressure, sometimes with fluid retention and proteinuria) in pregnant women (WHO/FOA, 2013). The highest recommended daily intake of calcium is $750-800 \mathrm{mg} /$ day as seen in Table 2. Excess Calcium in blood stream may result to nausea, poor appetite, vomiting and constipation (DGA, 2010). Amount of calcium was within MP in the Eh sample analyzed.

All living things need Sulphur, it is especially important for humans because part of the amino acid methionine, which is an absolute dietary requirement for us. The amino acid cysteine also contains sulphur. The average person takes in around $900 \mathrm{mg}$ of sulphur per day, mainly in the form of protein. Sulphuric substances can have Neurological effects and behavioural changes, Disturbance of blood circulation, Heart damage Effects on eyes and eyesight, Reproductive failure, Damage to immune systems, Stomach and gastrointestinal disorder, Damage to liver and kidney functions, Hearing defects, Disturbance of the hormonal metabolism, Dermatological effects, Suffocation and lung embolism (Obi et al., 2006). The Sulphur content in Eh of 4.128 $\mathrm{mg} / \mathrm{kg}$ will have no hazards with proper prescription for medicinal use.

Titanium is used in biomedical implants. Excessive exposure may lead to coughing and difficulty in breathing at the chest, and irritation on the eyes and skin.

$\mathrm{Fe}$ in human body has three main functions. It is a part of haemoglobin and is responsible for oxygen transport, maintains a healthy immune system and being a constituent of several enzymes, is responsible for energy production. It is also an active site for several enzymes. Fe deficiency is probably the most common nutritional deficiency in the world though it performs the most vital functions in the body. An estimate based on WHO criteria indicated that around 600-700 million people worldwide have marked iron deficiency anaemia especially in developing countries. In developed countries, the prevalence of iron deficiency anaemia is between $2 \%$ and 8\% (Jiang, and Genant, 2008). The MPL of iron as seen in Table 2 is 9.1-26.0 mg/day while in medicinal plant is $20 \mathrm{mg} / \mathrm{kg}$.

Iron salts have an astringent action resulting in irritation of the gastrointestinal mucosa, which gives rise to gastric discomfort, nausea, vomiting and diarrhea or constipation. Therefore, the presence of these symptoms commonly associated with the intake of some medicinal plants may be due to iron toxicity (Krishnamachari and Krishnaswamy, 1974). Amount of Iron in the sample was below the permissible limit. There is no recommended intake of Rubidium, intake of about $1.5 \mathrm{mg} /$ day is considered adequate, rubidium has tranquilizing effect and is also used in treatment of nervous disorders or epilepsy. No effect of deficiency or toxicity has been reported. The $B h$ sample was below $1.5 \mathrm{mg}$. Strontium helps in the proper functioning of neurons, formation of bones and teeth, excess $\mathrm{Sr}$ can cause nausea, diarrhea, headaches, fainting, blood clotting (https://www.lenntech. com/periodic/elements).

Zirconium is used in biomedical application such as dental implants, knee and hip replacements but can cause irritation to the skin and eyes. Zirconium and its salts generally have low systemic toxicity, most passes through the gut without being adsorbed, and that which is adsorbed tends to accumulate slightly more in the skeleton than in tissue. The daily human intake as shown in Table 2 is $125 \mathrm{mg} / \mathrm{day}$. The $E h$ plant contains low concentration of Zirconium of $0.026 \mathrm{mg} / \mathrm{kg}$, while Molybdenum is an essential element in human nutrition 
necessary for processing amino acids and acts as a catalyst for enzymes. Ingestion of 10-15 (mg/day) of molybdenum, for prolonged periods of time, may lead to an increase of uric acid in the blood. Lower-limb osteoporosis may be associated with ingestion of cereals with high molybdenum content. Mo is safe in amounts that does not exceed $2 \mathrm{mg}$ / day for human consumption (Chen, 2003).

Thorium increase chances of lung cancer and changes in genetic material of the body which open doors for diseases (Chen, 2003). Zinc is an essential component of many enzymes participating in the synthesis and degradation of carbohydrates, lipids, proteins, and nucleic acids as well as in the metabolism of other micronutrients. It stabilizes the molecular structure of cellular components and membranes and in this way contributes to the maintenance of cell and organ integrity. Furthermore, Zinc has an essential role in polynucleotide transcription and thus in the process of genetic expression. Its involvement in such fundamental activities probably accounts for the essentiality of $\mathrm{Zn}$ for all life forms. It plays a central role in the immune system, affecting a number of aspects of and humoral cellular immunity. $\mathrm{Zn}$ is an extremely important part of insulin and it is known to improve the sensitivity of insulin in the management of diabetes (Shankar and Prasad, 1998). FAO/WHO daily intake of $\mathrm{Zn}$ is $4.2-14.0 \mathrm{mg}$ /day while the permissible limit in medicinal plants is 50 $\mathrm{mg} / \mathrm{kg}$. Ingesting more than $200 \mathrm{mg} /$ day of $\mathrm{Zn}$ can cause abdominal pain, laziness, headache, anaemia, fever, nausea, vomiting and diarrhea.

The result clearly shows these elements present in the Euphobia hirta Eh as stated above and that their contents were within acceptable and safe limits as represented in Table 2. All reported values of the studied plants are in agreement with those previously reported in the literature (Olayiwola, 2013); (Guessan et al., 2015).

\section{Conclusions}

Toxic elements such as Nickle, Arsenic, Lead, Cadmium and Mercury were not detected in the plant sample, while all elements detected were below the MPL. Therefore, herbal formulations of this plant specie can also be beneficial sources of appropriate and essential elements.

The following recommendations were observed in the course of the study:

a) These plants extract contain mineral elements (calcium and potassium) and should be included in diets to supplement the body's daily need.

b) The use of other instruments such as Atomic Absorption Spectroscopy (AAS), Graphite Furnace Atomic Absorption Spectroscopy (GFAAS), Industrial Coupled Plasma Spectrometer - Optimal Emission Spectrometer (ICP-OES) can be employed to compare the elements contents of the plants

c) Medicinal plants are consumed like normal diet in our society; therefore consumption should be regulated by appropriate agencies.

\section{Conflict of interest}

None to declare.

\section{References}

Abdulmojeed OL and AA Abdulrahman, 2011. Analysis of heavy metals found in vegetables from some cultivated irrigated gardens in the Kano metropolis, Nigeria. J. Environ. Chem. Ecotoxicol., 3: 142-148

Abdulrahman FI and PA Onyeyili, 2001. Phytochemical screening and pharmacological activities of the stem bark of Terminalia avicennoides. Bull. Anim. Health Prods. Afr., 49: 236-242.

Adedapo AA, OO Shabi and OA Adedokun, 2005. Antihelminthic efficacy of theaqueous extract of Euphorbia hirta (Linn.) in Nigerian dogs. Vet. Arch., 75: 39-47.

Adoum UA, JA Akinniyi and I Umar, 1998. The effect of geographical location on the antimicrobial activity and trace element concentration in the root or Calotropis procera. Ann. Brono, 13-14: 199-207.

Aweng ER, M Karimah and O Suhaimi, 2011. Heavy metals concentration of irrigation water, soils and fruit vegetables in Kota Bharu Area, Kelantan, Malaysia. J. Appl. Sci. Environ. Sanit., 6: 463-470.

Ayodele SQ, 2003. The effects of herbal remedies.

Buhrke VE, R Jenkins and DK Smith, 1998. A Practical Guide for the Preparation of Specimens for X-Ray Fluorescence and X-Ray Diffraction Analysis. John Wiley \& Sons, Inc. QD96.X2P73 ISBN 0-471-19458-1.

Chen X, 2003. Hepatic function in previously exposed Thorium refinery workers as compared to normal control from health and nutritional survey. China Medical Journal, 11: 364-382.

Dghaim R, AK Safa, H Rasool and AK Munawwar, 2015. Determination of heavy metals concentration in traditional herbs commonly consumed in the United Arab Emirates. Journal of Environmental and Public Health, 10: 1155-1161.

Dietary guidelines for Americans (DGA), 2010. U.S. Department of Health and Human Services. 
Erick KT, KD Shepherda and BL Drakeb, 2015. Plant elemental composition and portable X-rayfluorescence (pXRF) spectroscopy: quantification under different analytical parameters. X-Ray Spectrometry published by John Wiley \& Sons, Ltd. X-Ray Spectrom. 45: 117-124.

Guessan BY, S Rokia, C Kiyinlma and K Diénéba, 2015. Minerals salt composition and secondary metabolites of Euphorbia hirta Linn., an antihyperglycemic plant. Pharmacognosy Res., 7: 7-13.

Jiang, Arlot and Genant, 2008. Histomorphometric and analysis of bones biopsies from post menpausal osteoporotic women treated with Strontium renelate. Journal of Bone and Mineral Research, 2: 215-222.

Krishnamachari KA and K Krishnaswamy, 1974. An epidemiological study of the syndrome of genu valgum among residents of endemic areas for fluorosis in Andhra Pradesh. Indian J Med Res., 62: 1415-1423.

Lynch E and R Braithwaite, 2005. A review of the clinical and toxicological aspects of traditional (herbal) medicines adulterated with heavy metals. Expert Opin. Drug Saf., 4:76-78.

Moses EA, VO Ogugbuaja and VC Ogarawu, 2002. Enrichment of element of Nigerian bituminous coal fly ash and their effects on haematological parameters of exposed rabbits. Nig. J. Exp. Applied Biol., 3: 95-100.

Obi E, DN Akunyili, B Ekpo and OE Orisakwe, 2006. Heavy metal hazards of Nigerian herbal remedies. Sci Total Environ., 369: 35-41.

Okwu DE and ON Ohenhen, 2010. Isolation and characterization of steroidal glycosides from the leaves of Stachyterpheta jamaicensis Linn Vahl. Pelgia Research Library. Der ChemicaSinica, 1: 6-14.

Olayiwola OA, 2013. Phytochemicals and spectrophotometric determination of metals in various plant. IJPSR, 6: $51-54$.

Shahid M, E Ferrand, E Schreck and C Dumat, 2006. Behavior and impact of Zireonium in the soil plant system, plant uptake and phytotoxicity. Rev. Environ. Contam. Toxicol., 221: 107-127.

Queralt I, M Ovejero, ML Carvalho, AF Marques and JM Llabres, 2005. Quantitative determination of essential and trace element content of medicinal plants and their infusionsby XRF and ICP techniques. X-Ray Spectrometry published by John Wiley \& Sons, Ltd. X-Ray Spectrom. 34: 213-217.

Shankar AH and AS Prasad, 1998. Zinc and immune function: the biological basis of altered resistance to infection. Am. J. Clin. Nutr., 68: suppl 447S-463S.

World Health Organisation (WHO), 2013. Guidelines: Calcium supplementation in pregnant women. Geneva: World Health Organization. pp. 31.

World Health Organization and Food and Agriculture Organization of the United Nations (WHO/FAO) (2004) Vitamin and mineral requirements in human nutrition. Report of a joint FAO/WHO expert consultation. World Health Organization and Food and Agriculture Organization of the United Nations; pp. 59-85. .

World Health Organisation (WHO), 1996. Trace elements in human nutrition and health. A Report of a reevaluation of the role of trace elements in human health and nutrition. WHO Technical Report Series, Geneva, pp. 119-205.

Yoshimura M, H Takahashi and T Nakanishi, 1991. Role of sodium, potassium, calcium, magnesium on blood pressure regulation and anti-hypertensive dietary therapy. Japanese Journal of Nutrition, 49: 53-63.

https://www.lenntech.com/periodic/elements/s.htm\#ixzz57zupx 8it 